\title{
Submission of FeCrAl Feedstock for Support of AFC ATR-2 Irradiations
}

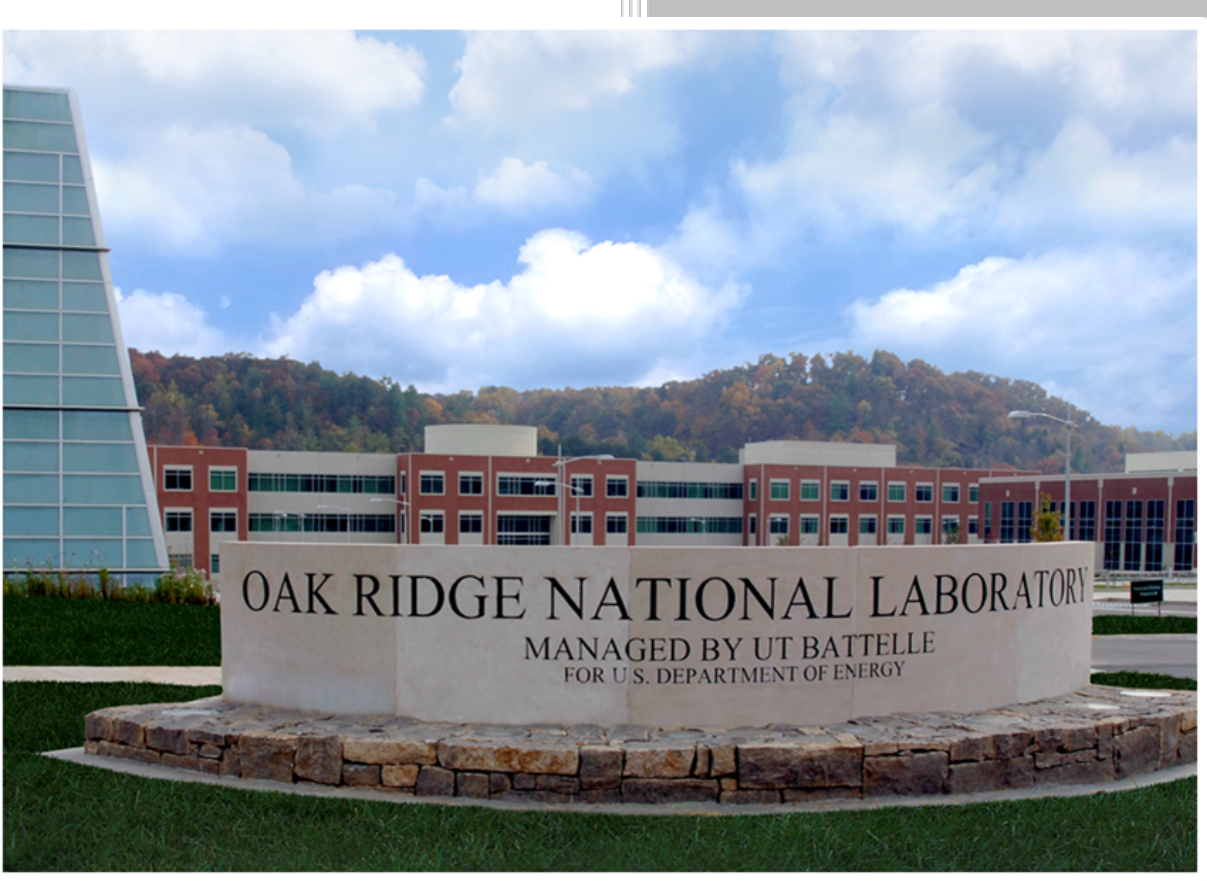

Kevin G. Field

Kristine Barrett

Zhiqian Sun

Yukinori Yamamoto

Approved for public release. Distribution is unlimited.

September $16^{\text {th }}, 2016$ 


\section{DOCUMENT AVAILABILITY}

Reports produced after January 1, 1996, are generally available free via US Department of Energy (DOE) SciTech Connect.

Website http://www.osti.gov/scitech/

Reports produced before January 1, 1996, may be purchased by members of the public from the following source:

National Technical Information Service

5285 Port Royal Road

Springfield, VA 22161

Telephone 703-605-6000 (1-800-553-6847)

TDD 703-487-4639

Fax 703-605-6900

E-mail info@ntis.gov

Website http://www.ntis.gov/help/ordermethods.aspx

Reports are available to DOE employees, DOE contractors, Energy Technology Data Exchange representatives, and International Nuclear Information System representatives from the following source:

Office of Scientific and Technical Information

PO Box 62

Oak Ridge, TN 37831

Telephone 865-576-8401

Fax 865-576-5728

E-mail reports@osti.gov

Website http://www.osti.gov/contact.html

This report was prepared as an account of work sponsored by an agency of the United States Government. Neither the United States Government nor any agency thereof, nor any of their employees, makes any warranty, express or implied, or assumes any legal liability or responsibility for the accuracy, completeness, or usefulness of any information, apparatus, product, or process disclosed, or represents that its use would not infringe privately owned rights. Reference herein to any specific commercial product, process, or service by trade name, trademark, manufacturer, or otherwise, does not necessarily constitute or imply its endorsement, recommendation, or favoring by the United States Government or any agency thereof. The views and opinions of authors expressed herein do not necessarily state or reflect those of the United States Government or any agency thereof. 
Fuel Cycle Research and Development (FCRD)

\section{Submission of FeCrAl Feedstock for Support of AFC ATR-2 Irradiations}

Kevin G. Field, Kristine Barrett, Zhiqian Sun, and Yukinori Yamamoto

Date Published: September $16^{\text {th }}, 2016$

Prepared by

OAK RIDGE NATIONAL LABORATORY

Oak Ridge, TN 37831-6283

managed by

UT-BATTELLE, LLC

for the

US DEPARTMENT OF ENERGY

under contract DE-AC05-00OR22725 



\section{CONTENTS}

Page

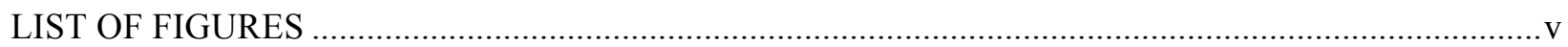

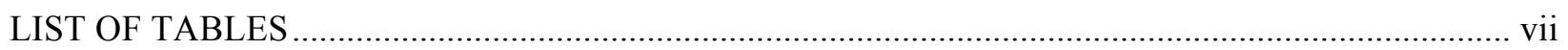

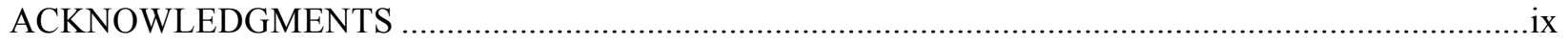

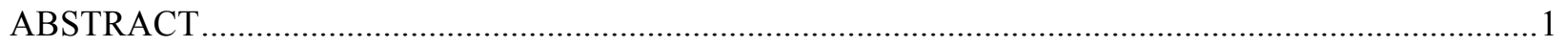

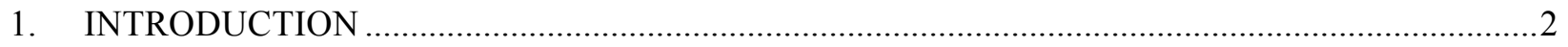

2. MATERIALS FOR SUPPORT OF AFC ATR-2 IRRADIATIONS ….........................................

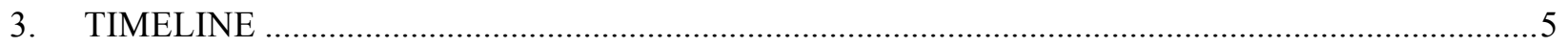

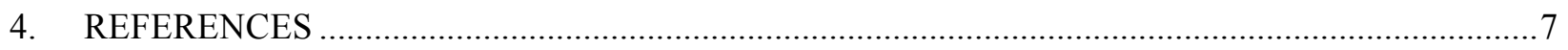





\section{LIST OF FIGURES}

Figure 1: Notional ATF-2 irradiation test train design. Figure courtesy of Brian Durtschi (INL) 3

Figure 2: Photograph showing FeCrAl alloy rod stock shipped to INL for autoclave testing and SQT.

Figure 3: Optical micrographs showing microstructure of the cross-section $(a, b)$ and the longitudinal-section (c, d) of the FeCrAl alloy rod stock shipped to INL; (a, c) C06M and $(b, d)$ C36M. . . .5

Figure 4: Notional schedule for ATF-2 irradiation program, Part 1 of 2 . ............................................ 6

Figure 5: Notional schedule for ATF-2 irradiation program, Part 2 of 2. ................................................. 



\section{LIST OF TABLES}

Table 1: Summary of FeCrAl alloy compositions in weight percent (wt.\%) unless otherwise noted. All other elements below $0.01 \mathrm{wt} . \%$. 



\section{ACKNOWLEDGMENTS}

Research was sponsored by the DOE's Office of Nuclear Energy, Advanced Fuel Campaign of the Fuel Cycle R\&D Program. 


\begin{abstract}
The Advanced Test Reactor (ATR) is currently being used to test accident tolerant fuel (ATF) forms destined for commercial nuclear power plant deployment. One irradiation program using the ATR for ATF concepts, Accident Tolerant Fuel-2 (ATF-2), is a water loop irradiation test using miniaturized fuel pins as test articles. This complicated testing configuration requires a series of pre-test experiments and verification including a flowing loop autoclave test and a sensor qualification test (SQT) prior to full test train deployment within the ATR. In support of the ATF-2 irradiation program, Oak Ridge National Laboratory (ORNL) has supplied two different Generation II FeCrAl alloys in rod stock form to Idaho National Laboratory (INL). These rods will be machined into dummy pins for deployment in the autoclave test and SQT. Post-test analysis of the dummy pins will provide initial insight into the performance of Generation II FeCrAl alloys in the ATF-2 irradiation experiment as well as within a commercial nuclear reactor.
\end{abstract}




\section{INTRODUCTION}

The events that occurred at the Fukushima Daiichi nuclear power plant in 2011 has sparked renewed interest in fuel-clad systems which can have increased performance in design basis and beyond design basis accident scenarios. As part of this renewed interest, the Department of Energy Nuclear Energy (DOE-NE) developed a Research, Development, and Demonstration (RD\&D) program for light water reactor (LWR) fuel-clad with enhanced accident tolerance under the Accident Tolerant Fuel (ATF) program focus. The ATF program is currently tasked to field a lead fuel rod or lead fuel assembly within a commercial LWR by 2022. To meet this goal, a series of irradiation programs have been conceptualized including a series of different irradiation tests within the Advanced Test Reactor (ATR) at Idaho National Laboratory (INL).

The first series of ATR testing, deemed ATF-1, was focused on simple, quick to deploy drop-in capsule experiments. These experiments were developed to demonstrate the capabilities within the Advanced Fuels Campaign (AFC) to field novel accident tolerant fuel-clad systems within a neutron exposure environment. Of particular interest is the hermeticity of welds and clad tubing, fuel-clad performance, and structural stability of the test train. ATF-1 utilized an already deployed experimental test configuration that incorporated a double encapsulated design. Hence, the ATF-1 design does not provide any clad-coolant interactions during irradiation. Clad-coolant interactions are of particular importance as many ATF designs use replacement materials for $\mathrm{Zr}$ based cladding material. For example, one such design is the use of FeCrAl cladding with commercial $\mathrm{UO}_{2}$ fuel. Details on the ATF-1 FeCrAl cladding test train has been previously reported [1].

A follow on study to the ATF-1 irradiation program has been conceptualized and is currently in development. This program, named ATF-2, ditches the double encapsulated design in favor of a test loop where novel clad and fuel-clad designs can be tested in a neutron environment that is simultaneously being exposed to prototypical pressurized water reactor (PWR) coolants. The primary goal of the ATF-2 is to demonstrate concept viability thus bringing key technologies further into commercial maturity.

The ATF-2 irradiation program brings new capabilities within the AFC. The final design consists of a $2 \times 3$ arrangement of one 12 inch and four 6 inch tiers of candidate fuel pins. The stationary top tier (Tier 5) has been designated as an instrumented portion of the experiment as shown in the schematic in Figure 1. Hence, a complicated arrangement of sensors is needed to quantify values such as irradiation temperature, neutron flux, fuel and clad dimensional changes, pressure, among others. Some of these sensors have been widely deployed in previous experimental configurations, but many of them are still technologically immature. Prior to ATF-2 deployment, it has been identified that a Sensor Qualification Test (SQT) must be completed to verify the validity of using the pre-defined sensor configuration pack within the program. 


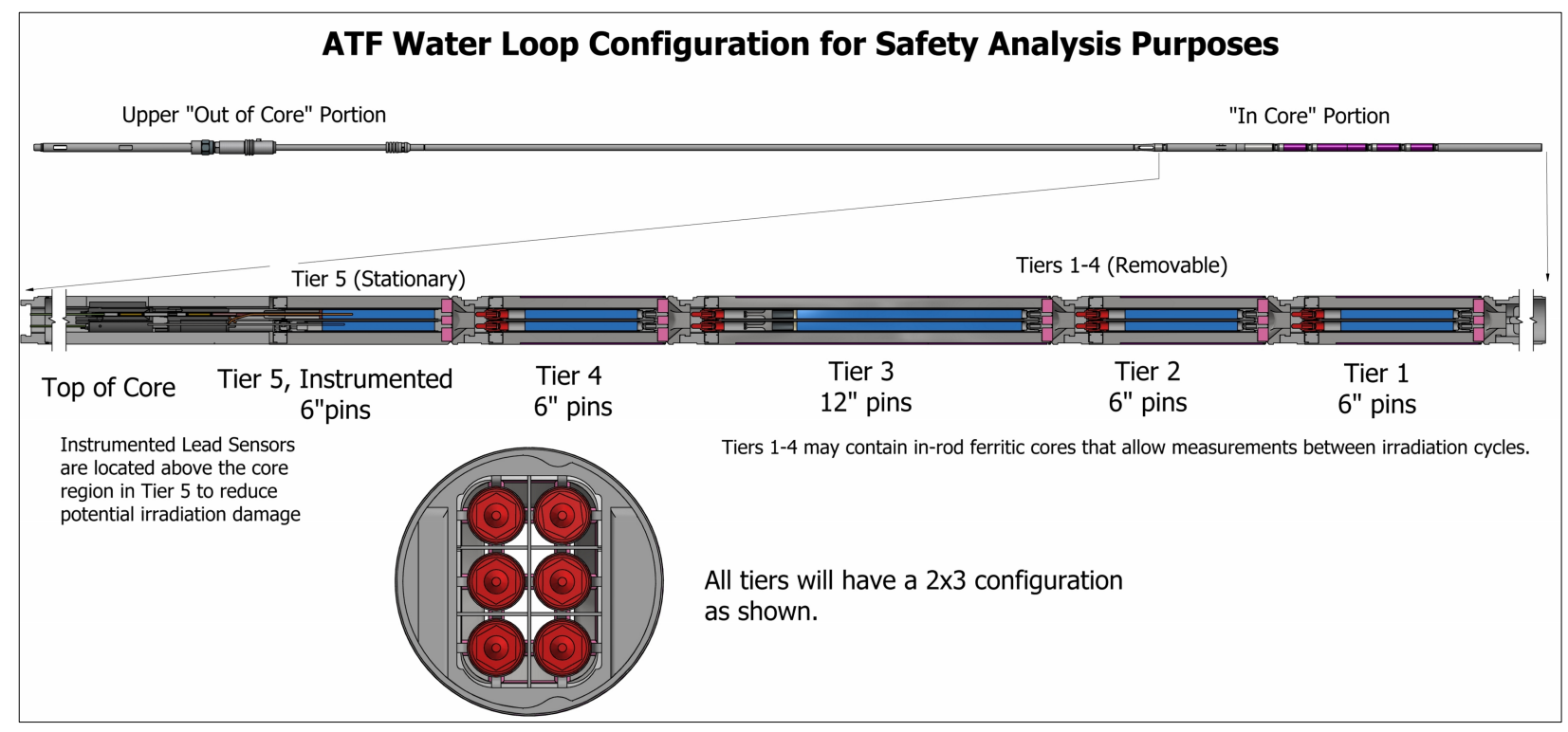

Figure 1: Notional ATF-2 irradiation test train design. Figure courtesy of Brian Durtschi (INL).

The objective of the SQT in the ATR is to test and evaluate sensor performance under prototypic PWR loop conditions prior to insertion in the fueled ATF-2 test train. Since none of the sensors planned for the SQT have been exposed to high flow conditions planned in the ATR water loop, it is advantageous to perform an out-of-pile test to evaluate sensor performance prior to ATR insertion. This test is an out-of-pile flowing loop autoclave test. This fundamentally lower cost and simpler logistic experiment is intended to determine if the sensor pack will perform under ATR's typical water flux, chemistry, pressure, and temperatures prior to the SQT and the final ATF-2 test. The Westinghouse autoclave facility has been identified as the facility for this preirradiation autoclave tests. The autoclave test is scheduled to be performed for two weeks within the Winter of 2017.

Both tests, the SQT and autoclave tests, require "dummy" test specimens to evaluate chemical compatibility and potential corrosion due to exposure to PWR chemistry prior to insertion of the fueled test train in the ATR. Currently, Oak Ridge National Laboratory (ORNL) has been manufacturing commercial-scale heats of several different Generation II FeCrAl cladding alloys for use within the AFC. It has been identified that these commercial heats of candidate FeCrAl cladding could be used as cladding material during the autoclave test and SQT. Use of the $\mathrm{FeCrAl}$ alloys will provide critical preliminary information on the performance of these alloys in PWR-like environments while assisting in the ATF-2 objectives. The following report outlines the materials supplied to the ATF-2 design team in support of the autoclave test, the SQT, and the ATF-2 experiments. 


\section{MATERIALS FOR SUPPORT OF AFC ATR-2 IRRADIATIONS}

The materials selected to support ATF-2 activities are ORNL developed Generation II FeCrAl alloys. These alloys have Mo additions to the base Generation I alloys to promote better high temperature strength. Table 1 summarizes the complete composition of both alloys provided. Both alloys are in the form of 14 inch by $7 / 8$ inch diameter rod stock, Figure 2 . The rods are marked in white marking with labels of "C36M3 ORNL" and "C06M2 ORNL". These markings signify the alloy and heat ID, e.g. C36M is the alloy and it's the $3^{\text {rd }}$ heat of its kind. Both alloys were manufactured using vacuum induction melting (VIM) followed by extrusion and then annealed at $800^{\circ} \mathrm{C}$.

Table 1: Summary of FeCrAl alloy compositions in weight percent (wt.\%) unless otherwise noted. All other elements below 0.01 wt.\%.

\begin{tabular}{|c|c|c|c|c|c|c|c|c|c|c|c|}
\hline \multirow{2}{*}{ Alloy } & \multicolumn{10}{|c|}{ Composition (wt \%) } \\
\cline { 2 - 14 } & Fe & Cr & Al & Y & C & S & O & N & P & Si & Mo \\
\hline C06M & 81.84 & 9.88 & 6.03 & 0.05 & 0.003 & $5 \mathrm{ppm}$ & 0.0034 & 0.0004 & 0.005 & 0.21 & 1.97 \\
\hline C36M & 78.8 & 12.98 & 6.00 & 0.040 & 0.003 & $<3 \mathrm{ppm}$ & 0.0016 & 0.0002 & $<0.002$ & 0.180 & 1.98 \\
\hline
\end{tabular}

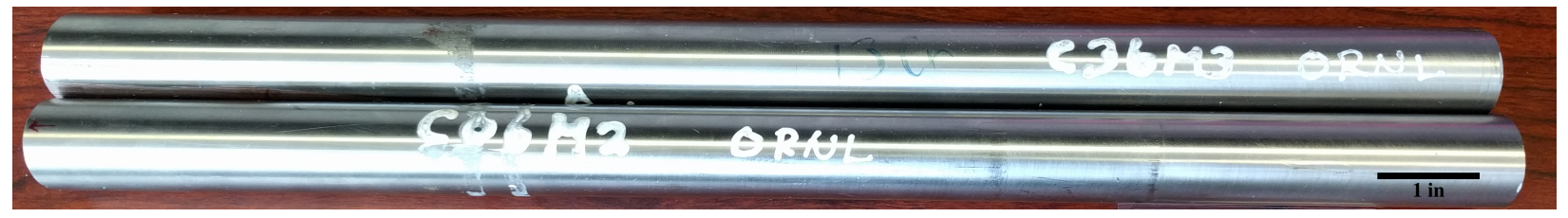

Figure 2: Photograph showing FeCrAl alloy rod stock shipped to INL for autoclave testing and SQT.

Figure 3 represents the optical micrographs of the FeCrAl rod stock, C06M and C36M, provided to INL. Both materials consisted of a mixed microstructure with recrystallized grains and nonrecrystallized, elongated grains along the longitudinal axis (parallel to the extrusion axis). Although the microstructure looks quite non-uniform, both materials exhibited relatively uniform Vickers hardness distributions with the average values of $210 \pm 5 \mathrm{HV}$ and $224 \pm 6 \mathrm{HV}$ for C06M and C36M, respectively. These hardness values are sufficiently low in this class of FeCrAl alloys, indicating that the provided $\mathrm{FeCrAl}$ rod stock were in the fully annealed conditions. Therefore, it is noted that very little microstructure changes attributed to the status of asdelivered materials (e.g. residual strains) would be expected during elevated temperature autoclave testing or irradiation testing.

The submitted rod-stock will be used for the manufacturing of solid rod dummy-pins, i.e. the components will not contain $\mathrm{UO}_{2}$ fuel pellets. Each dummy pin is intended to be 6.820 inch in length and 0.374 inch in diameter. Hence, at least two dummy pins can be manufactured from each supplied rod. 


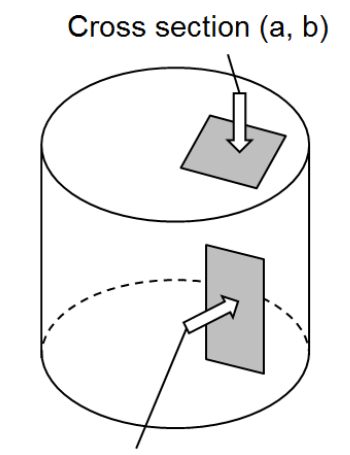

Longitudinal section $(c, d)$
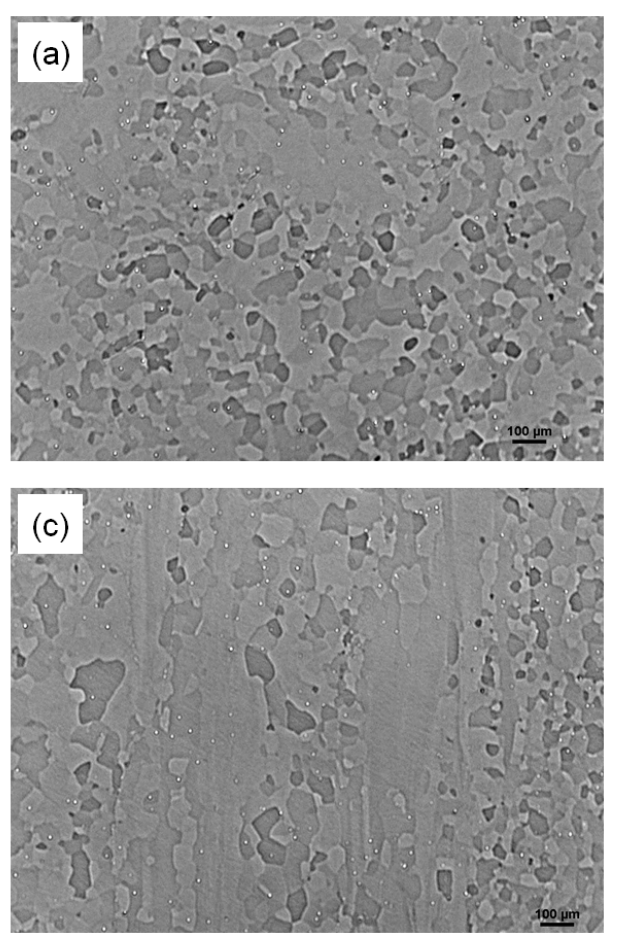
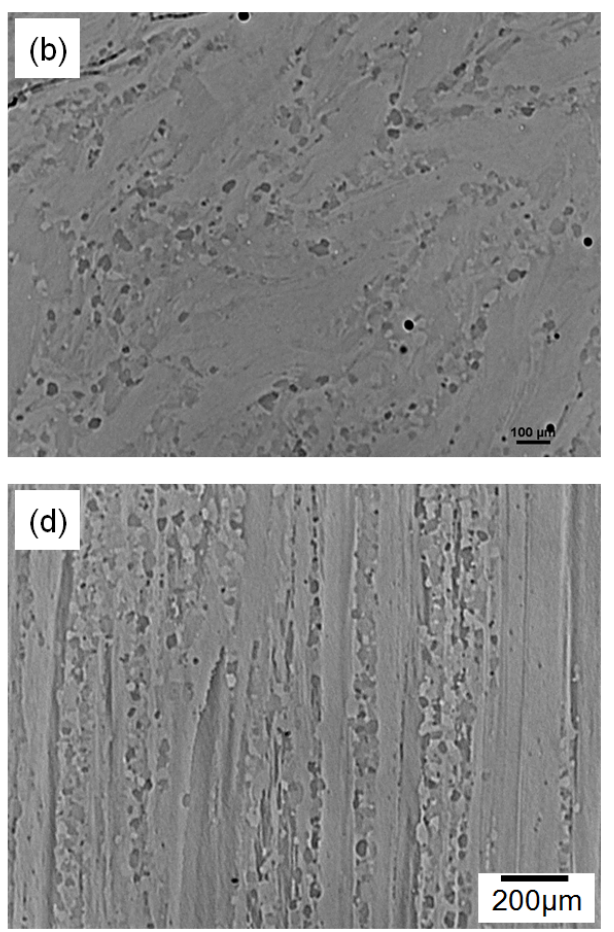

Figure 3: Optical micrographs showing microstructure of the cross-section $(a, b)$ and the longitudinal-section (c, d) of the FeCrAl alloy rod stock shipped to INL; (a, c) C06M and (b, d) C36M.

\section{TIMELINE}

Figure 4 and Figure 5 provide a Gantt chart with the notional schedule for the SQT, autoclave, and ATF-2 tests. Currently, the autoclave test is scheduled for the end of January 2017.

Machining of components precedes this test and should complete fabrication in late December 2016. The SQT fabrication is currently ongoing and anticipated to be completed in Spring 2017 followed by irradiation in ATR cycle 162A, which is currently scheduled for startup in Spring 2017. The rod stock was received by INL fabrication facilities on August $10^{\text {th }}, 2016$, hence meeting the required timeline for insertion into both the autoclave and SQT tests. Furthermore, post-test inspections of these test articles can be completed in 2017, enabling informed decisions about the performance of Generation II FeCrAl alloys in prototypical PWR irradiation and coolant conditions. 


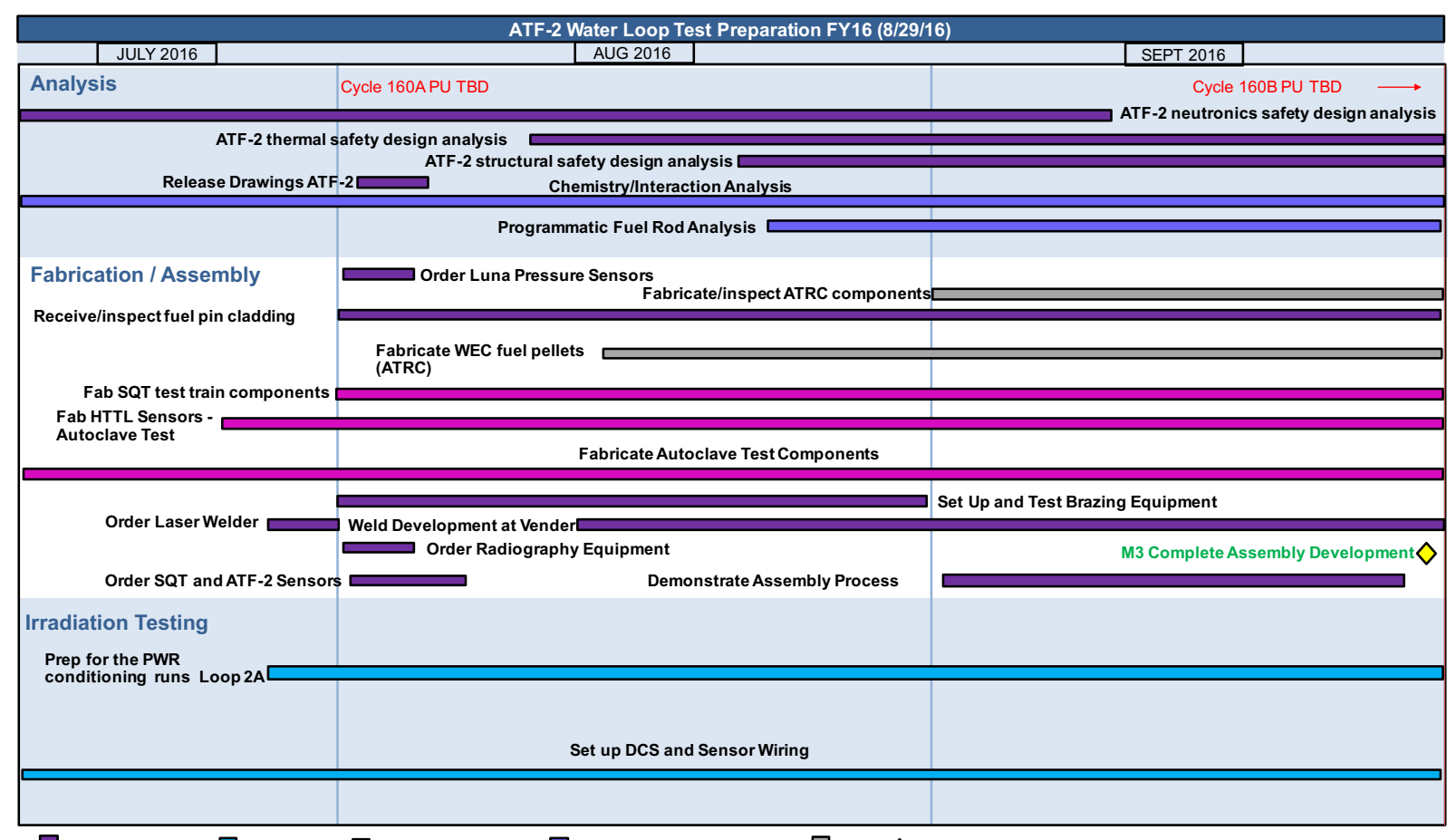

$\square$ ATF-2 Fuel Test $\square$ ATR Safety $\square$ SQT/Autoclave Test $\square$ Programmatic Analysis $\square$ MFC $\diamond$ Milestones

Figure 4: Notional schedule for ATF-2 irradiation program, Part 1 of 2.

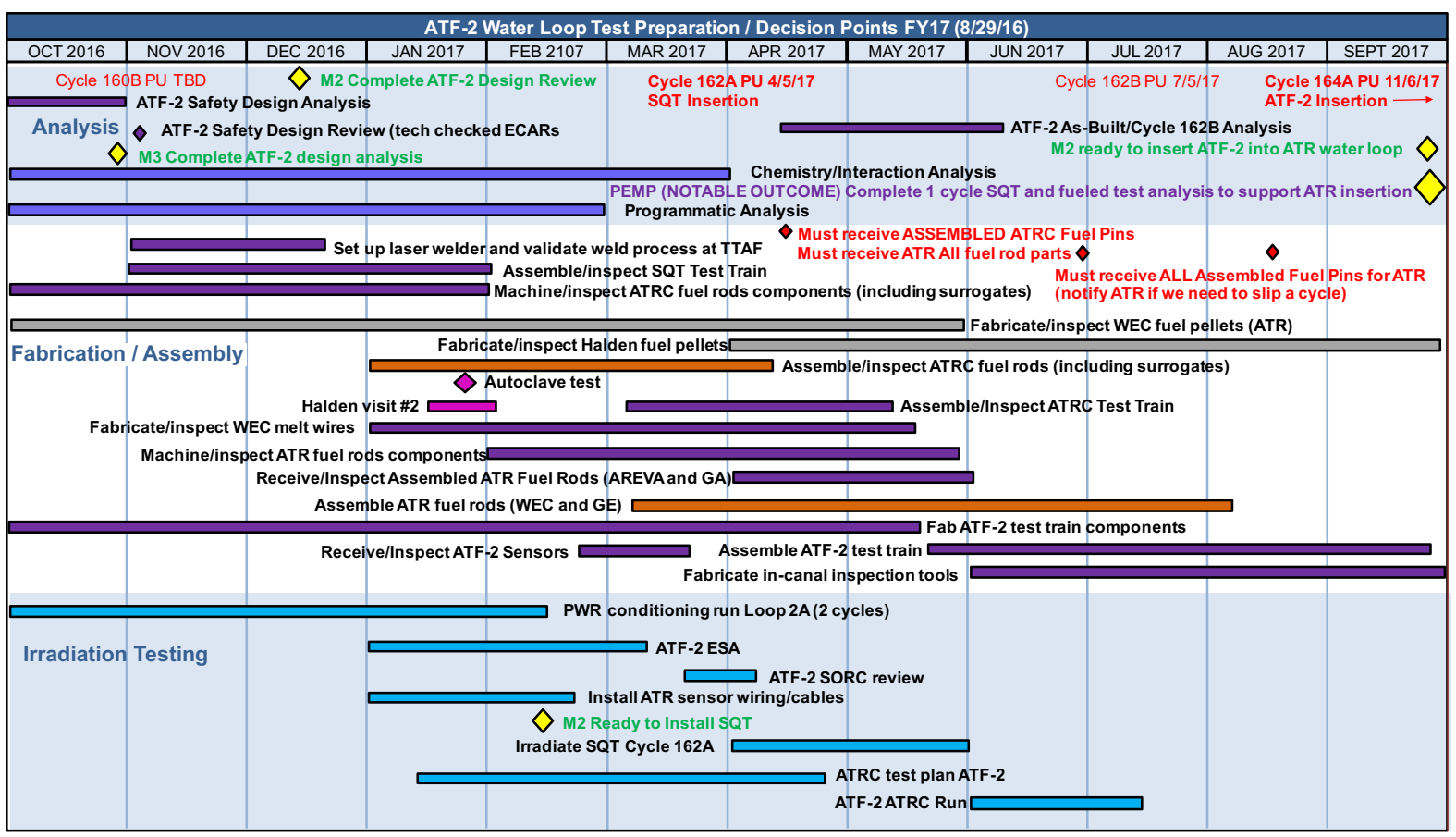

$\square$ ATF-2 Fuel Test $\square$ ATR Safety $\square$ PM $\square$ Autoclave Test $\diamond$ Decision Points $\diamond$ Milestones $\square$ Programmatic Analysis $\square$ MFC $\square$ HTTL, MFC, TTAF

Figure 5: Notional schedule for ATF-2 irradiation program, Part 2 of 2. 


\section{REFERENCES}

[1] K.G. Field, R.H. Howard, M. Teague, Fabrication control plan for ORNL ATF test specimens to be irradiated in the ATR, Idaho National Laboratory, Idaho Falls, ID, 2014. 